\title{
Notes
}

\section{Pardon Me?: The Constitutional Case Against Presidential Self-Pardons}

\author{
Brian C. Kalt
}

August 1, 1974. As Richard Nixon's presidency rapidly neared its end, his aides outlined his options. One possibility discussed was for Nixon to pardon himself and then resign. His lawyers prepared a short memorandum concluding that a self-pardon would be legal.' Nevertheless, Nixon decided against a selfpardon, resigned, and left his fate in the hands of President Gerald Ford.'

Christmas Eve 1992. President George Bush had lost his bid for reelection and would be in office for only one more month. Special Prosecutor Lawrence Walsh had persisted in his pursuit of Iran-Contra suspects. Bush decided to pardon several of them, leaving himself as the most prominent prosecutable figure. ${ }^{3}$ Several commentators speculated that Bush might pardon himself for his role in the scandal, and many assumed that such an act would be valid." One stated, "[F]or a president to pardon himself would, admittedly, be an act of unprecedented chutzpah, but the Constitution does not forbid it, containing nothing that circumscribes the power ...." Others disagreed, including Walsh and his staff. ${ }^{6}$ As one commentator wrote: "We have not recognized

1. See Bob Woodward \& Carl Bernstein, The Final Days 325-26 (1976). Daniel Schort, Will Bush Pardon Himself?, Baltimore EVENing SUN, Dec. 30. 1992, at 13A. Nixon Chief of Siaff Alexander Haig claims the memo was written by Nixon's lawyer, J. Fred Buzhardt, but President Ford's aides say " was prepared by Special Counsel James St. Clair. See Schorr, supra.

2. Of course, President Ford pardoned President Nixon. See Proclamauon No 4311. 39 Fed Reg 32,601 (1974).

3. See Schor, supra note 1 (discussing Bush's exposed stalus and Walsh's plans to call Bush before grand jury); Pete Yost, The 'Cleansing' Effect May Not Work. Associated Press Pol. Ser. Dec 25, 1992. available in 1992 WL 5157491 ("Walsh now accuses Bush of 'misconduct.' . . (Flor the first tume, Walsh said Bush was the subject now of our investigation." ).

4. See, e.g., James Gill, Walsh's Quarny. New ORLEANS TIMES-PICAYUNE, Jan 1. 1993, at B7. Schor. supra note 1.

5. Gill, supra note 4 (internal quotation marks omitted).

6. See Larry Bensky, Burying Iran-Contra. S.F. CHRON.. Jan. 17. 1993, at 7Rl (reportung that Walsh staffer says Bush "can't pardon himself"); Saul Friedman. Prosecutor Bashes Bush. NEwsDaY, Dec 26. 1992, at 4 (reporting that source "close to the investigation" says that there is "no question that a prestdent 
the power of a president ... to pardon himself. On the contrary, one of the most fundamental principles of justice is that a person shall not sit in judgment of himself." In the end, like Nixon, Bush did not pardon himself. His gamble paid off; he was not indicted. ${ }^{8}$

\section{THE PARDON POWER}

The President's power to pardon is stated simply in the Constitution: The President "shall have Power to grant Reprieves and Pardons for Offences against the United States, except in Cases of Impeachment." By limiting pardons to "Offences against the United States," the Constitution means to place private civil and state criminal cases beyond the President's reach. ${ }^{10} \mathrm{By}$ excepting "Cases of Impeachment," the Constitution stays the President's hand when Congress is doing the prosecuting instead of the executive branch. The President cannot stop the House from impeaching a federal official, nor can he undo the punishment the Senate doles out upon conviction. ${ }^{11}$

Other than these limitations, the President's power seems plenary and quite flexible. Pardons can be granted at any time after a crime has been committed: before federal criminal charges are brought, after conviction and sentencing, or any time in between. ${ }^{12}$ They can even be granted after the full sentence has been served, solely to restore the pardonee's civil rights. ${ }^{13}$ The President can give amnesty to a vast group of federal offenders, ${ }^{14}$ or he can pardon a single offender for a broad, unspecified range of crimes. ${ }^{15} \mathrm{He}$ can reimburse fines

cannot pardon himself"); All Things Considered: Can a President Pardon Himself? (NPR radio broadcast, Dec. 25, 1992), transcript available in LEXIS, News Library, NPR File (reporting that Walsh "doubts" President can pardon himself).

7. Robert Norris, Pretrial Pardon Raises Thomy Issues, Dallas MORNING News, Jan. 2, 1993, at 29A (editorial by lawyer/professor); see also Betty Parham \& Gerrie Ferris, $Q$ \& $A$ on the News, ATLANTA J. \& CONST., Dec. 3, 1992, at A2 ("[A] self-pardon would be a tricky proposition and open to challenge.").

8. See Saul Friedman, Pardon Pirouette: Walsh to Drop Iran-Contra Prosecutions, NEwSDAY, Dec. 31, 1992, at 7 .

9. U.S. CONST. art. II, $\$ 2$, cl. 1 .

10. See William F. Duker, The President's Power to Pardon: A Constitutional History, 18 WM. \& MARY L. REV. 475, 525-26 (1977). A pardon can release the offender from civil liability as to the federal govemment, provided that the claims of third parties are not impaired. See W.H. HUMBERT, THE PARDONING POWER OF THE PRESIDENT 54 (1941).

11. See EDWARD S. CORWIN, THE PRESIDENT: OFFICE AND POWERS, 1787-1984, at 190 (Randall W. Bland et al. eds., 5th ed. 1984). The punishment for impeachment is enumerated in the Constitution as "removal" and "disqualification" from ever holding federal office. U.S. CONST. art. I, $\S 3, \mathrm{cl} .7$.

12. See Ex parte Garland, 71 U.S. (4 Wall.) 333, 380 (1866); see also Murphy v. Ford, 390 F. Supp. 1372 (W.D. Mich. 1975) (confirming validity of Ford's pardon of unindicted ex-President Nixon). If a pardon were issued before the crime were committed, it would not be a pardon but rather a suspension of the law. See HUMBERT, supra note 10 , at 63 \& n. 45 .

13. See HUMBERT, supra note 10 , at 22 .

14. See Armstrong v. United States, 80 U.S. (13 Wall.) 154, 155-56 (1871). President Carter gave such an amnesty to Vietnam War draft evaders. See CORWIN, supra note 11, at 198.

15. Ford pardoned Nixon "for all offenses ... which he ... has committed or may have committed or taken part in." Proclamation No. 4311, 39 Fed. Reg. 32,601, 32,602 (1974). 
and forfeitures, ${ }^{16}$ grant reprieves, ${ }^{17}$ free prisoners, commute sentences, ${ }^{18}$ or attach a range of creative conditions to any of these options. ${ }^{19}$ The only restraints on the pardon power that have been formally recognized are those explicit in the text of the Pardon Clause. This Note contends, however, that a further limitation on the President's power, a preclusion of self-pardons, is implicit in the Constitution.

The cases of Presidents Nixon and Bush, and most recently of President Bill Clinton, ${ }^{20}$ have raised the specter of such self-pardons. Despite the potential political and historical magnitude of such an act, and despite the disagreement among those who have discussed its legality, the self-pardon has received little attention from scholars."

This Note is intended to remedy that neglect and make a constitutional argument against the validity of self-pardons. It does so by applying the most widely recognized methods of constitutional analysis: historical, textual, structural, and doctrinal (precedential). ${ }^{22}$ While there is some overlap between these methods, each of the arguments is presented here as analytically distinct. This Note does not claim that any of these analytic modes alone provides a

16. See Osborn v. United States, 91 U.S. 474,477 (1875).

17. See HuMBERT, supra note 10, at 22.

18. See Biddle v. Perovich, 274 U.S. 480 (1927).

19. See, e.g., Ex parte Wells, 59 U.S. (18 How.) 307 (1855) (approving condilional pardons). CoRwis. supra note 11, at 198-99 (approving conditional amnesties): HUMBERT. supra note 10, at $47 \&$ nn.57-58 (approving conditional commutations).

20. See, e.g., Peter Ferrara, Could President Pardon Himself?. WASH. TIMES. Oct. 22. 1996, at Alt (arguing that Presidents can pardon themselves); Frank J. Murray. Clinion's Wonds Fuel Pardon Talk. WASH. TIMES, Sept. 25, 1996, at Al (discussing legality of Clinton self-pardon); Paul Craug Roberts, Getting the Sordid Whitewater Drift, WASH. TIMES. Dec. 24, 1993. at Al6 (suggesung Clinion may pardon himself for his alleged Whitewater offenses).

21. Even the four legal scholars who discuss the presidential self-pardon in the legal literature do so only in passing. See Duker, supra note 10, at 504 (implying President can pardon seln): Enc M. Frecdman. The Law as King and the King as Law: Is a President Immune from Crminal Prosecution Before Impeachment?, 20 Hastings CoNST. L.Q. 7, 58 \& n.159 (1992) (presupposing President can pardon seln: Peter M. Shane, Presidents, Pardons, and Prosecutors: Legal Accountability and the Separation of Powers. 11 YALE L. \& PoL'y REv. 361, 404 n.196 (1993) (hypothesizing coun could find that President cannot pardon self); Peter M. Shane, Who May Discipline or Remove Federal Judges?, 142 U. PA. L. REV 209. 230 n.72 (1993) (doubting that President can pardon self); Akhil Reed Amar. On Judicıal Impeachment and Its Altematives-Remarks Prepared for the National Commission on Judieial Discipline and Removal 4 n.4 (Dec. 18, 1992) (notes for speech, on file with the Yale Law Joumal) (supposing hypothetucally that President can pardon self). Amar has since remarked in an interview that a self-pardon would be "awkward," "troubling," and possibly a crime and grounds for impeachment. See Murray. supra note 20.

22. This typology is taken from PHILIP BOBBIT,. CONSTITUTIONAL FATE: THEORY OF THE CONSTITUTION (1982). Bobbitt enumerates five main types of constitutional interpretanon: the four mentioned here, and "prudential" interpretation. See id. at 7. This Note does not make a prudentual argument because, as Bobbitt notes, such arguments are "actuated by the political and economic circumstances surrounding the decision" by the (prudentialist) cour. Id. at 61. Because this Niore is arguing in the abstract, there are no such "circumstances" to apply. The historical precedents that inform any discussion of self-pardons do enter into this analysis in Subsections III.B.3 and 4. however. and so there are some traces of prudential arguments there.

Bobbitt suggests, somewhat tentatively, adding a sixth mode to the canon: the "ethical" argument that derives decisions from the ethos of the American polity. See id. at 93-94. Given the uncernin status of this mode in the canon, it is not treated separately here. The doctrinal argument of Part IV, however, resembles at times a Bobbitt-like ethical interpretation. 
definitive answer to the question of self-pardons. Considered together, however, they show that the argument for legality is grossly oversimplified, and that the evidence for the unconstitutionality of presidential self-pardons is substantially stronger.

Part II makes the historical argument, examining original intent and the English history that informs it, and concludes that the Framers did not intend to allow self-pardons. Part III makes the textual and structural arguments, attacking the simple "plenary" reading and concluding that the best readings of the Constitution are structural ones that forbid Presidents from pardoning themselves. Part IV makes the doctrinal argument, supplementing the originalist and structural views by discussing the case law of pardons and the broader precedential principles of self-judging and the rule of law. Part V concludes that we should debate the unconstitutionality of self-pardons now, in the absence of a constitutional crisis, rather than wait for the problem to occur.

\section{HISTORY AND INTENT}

This Part makes an originalist argument by examining the historical background of the English pardon power and the discussion of pardons at the Constitutional Convention. This evidence will suggest that, on balance, the Framers did not affirmatively intend self-pardons to be valid.

\section{A. The English Roots of the Pardon}

The American pardon power was inherited directly from its English royal counterpart. ${ }^{23}$ To understand the meaning of American pardons at the time of the Founding it is thus important to explore the history of the pardon power in England. This history reveals three facts that are important for our purposes. First, the English pardon power was one of broad royal fiat, which fit uncomfortably with American notions of a limited executive. ${ }^{24}$ Second, Parliament eventually restricted the King's pardon power in ways that are important to understand in answering the question of self-pardons. Third, and most directly, self-pardons were a nonissue in England, making it impossible to determine their validity in America solely by looking to English precedent.

English monarchs had the power to pardon well before the Norman Invasion. ${ }^{25}$ In the early centuries, pardons had little to do with mercy. Two popular rationales for extending royal clemency were raising money and

23. See, e.g., HUMBERT, supra note 10, at 134 (discussing influence of English "ideas of clemency" on American pardon power).

24. This point relates not only to original intent, but also to the structural and doctrinal arguments in Subsection III.B.2.a and Section IV.A, infra.

25. See HuMBERT, supra note 10, at 9; Duker, supra note 10, at 476. 
raising armies: Early pardonees often gave either a cash payment or a promise to serve in the military. ${ }^{26}$

Over the years, various Kings expanded and consolidated the power, ignoring a series of attempts by Parliament to limit it. ${ }^{27}$ By the middle of the sixteenth century, the royal pardon power was absolute, giving the King the "authority to pardon or remit any treasons, murders, manslaughters or any kind of felonies ... or any outlawries for such offenses . . committed ... by or against any person or persons in any part of this Realm." ${ }^{.28}$ A royal pardon only applied, however, to offenses against the state; the remedies of private prosecution and personal reparations remained for wronged individuals. ${ }^{29}$

In England, there was no question about self-pardons or their legality because there could be no such thing as criminal executive action. "The law suppose[d] it impossible that the king himself [could] act unlawfully or improperly"; $;{ }^{30}$ there was nothing that the King could do that would require a pardon. Of course, Parliament could, and occasionally did, exercise an extralegal option-removing the King-in response to which a self-pardon would have been useless. ${ }^{31}$

In the late seventeenth century, Parliament was finally able to limit the royal pardon power legally instead of extralegally. Its actions were in response to an episode involving the impeachment of the Earl of Danby. ${ }^{32}$ The Earl, Thomas Osborne, was a Lord High Treasurer of England under King Charles II. In December of 1678, Parliament began impeachment proceedings against him for conspiring with France..$^{33}$ It was the King, however, who was making deals with the French; Danby was merely acting ministerially. Parliament realized this, but the King was "beyond reach" of legal remedies; impeaching the hapless Treasurer was the best that Parliament could do." Unfortunately for Parliament, the King revealed in March 1679 that he had issued a pardon

26. See Duker, supra note 10 , at 478-79 \& n.26. Duker's examples are iaken from the 1300 see also Stanley Grupp, Some Historical Aspects of the Pardon in England. 7 AM J LEGAL Hist 51. 59 (1963) (asserting that pardons were often given "as a means of financial explottalton")

27. See Duker, supra note 10, at 477-87, 493: see also HuMBert. supra note 10, at 9-10 (demonstrating how King's use of power often prompted Parliament to enact further restnctions)

28. Act for Continuing Certain Liberties of the Crown. $27 \mathrm{Hen} .8$. ch. 2\$. $\$ 1(1535-36)$ (Eng.) (spelling modernized).

29. See Duker, supra note 10, at 486. Similarly, the Amencan pardon is limited to enmes and public civil suits, as opposed to private civil remedies; the Unıted Siates has no instutution comparable to pnvate prosecution.

30. Joseph Chitty. A treatise on the Law of the Prerogatives of tie Crowiy 5 (London, Joseph Butterworth and Son 1820).

31. King Edward II (1327), King Charles I (1649), and King lames II (1688) were all deposed by Parliament.

32. For a detailed account of the Danby episode, see Duker, supra note 10, al 487-95

33. See id. at 488 . The grounds of the charge were that Danby had untten a letter to the Bntush ambassador in France that empowered the ambassador to make an offer of neutraluty as belween France and Holland for a price of 600,000 livres. Days earlier. however. Parliament had begun preparations for war against France. See id.

34. See id. 
for Danby. If Charles had only been trying to protect Danby he could have pardoned the Earl in December, but the King was now acting to solve a different problem. An examination of Danby's actions would have revealed that Charles had been receiving bribes from France; a pardon would end the investigation and spare the King this embarrassment. ${ }^{35}$

The King's action sparked a "constitutional confrontation"36 with Parliament, which had come to rely on the impeachment power to ensure proper governance. If the King could foil impeachments, Parliament would have no means of controlling his ministers. ${ }^{37} \mathrm{~A}$ debate raged as to the legality of Charles's action. ${ }^{38}$ Those who believed the Danby pardon to be invalid looked poised to win the argument, but the King defused the crisis by dismissing Parliament. ${ }^{39}$ Charles won the battle but the monarchy lost the war: In the 1701 Act of Settlement, Parliament forbade pardons from being used to preempt impeachments. ${ }^{40}$ The King could still pardon and reappoint his officials after they had been convicted by Parliament, but he could not subvert the impeachment process and thereby cover up his own misdeeds. ${ }^{41}$ The King was still above the law, to be sure, but the newly restricted pardon power provided a little less insulation.

The Framers thus inherited a model of the pardon power-broad royal fiat - that would have to be adapted to fit the more circumscribed office of the presidency. The Danby episode vividly showed the danger of giving the executive an unrestricted power to pardon. As we will see, the appearance of the Danby scenario in the Convention debates casts light not only on the limits of the pardon power in general, but also on self-pardons in particular. ${ }^{42}$

\section{B. The Framers}

This Section argues that the Framers' deliberations at the Convention provide evidence against the validity of self-pardons. In particular, the Framers did not see the pardon power as putting the President above the law. Whether this was because they opposed self-pardons or because they failed to consider

35. See id. at 489 n.67. This bears an interesting resemblance to the claims alleged against President Bush, see supra text accompanying notes 3-8; infra text accompanying notes $118-23$, and, to a lesser extent, President Clinton, see Murray, supra note 20.

36. Duker, supra note 10 , at 489.

37. See id.

38. See id. at $489-95$.

39. See id. at 495. Danby remained imprisoned, untried, in the Tower of London for five more years despite his pardon. See id. at $495 \&$ n.97.

40. See $12 \& 13$ Will. 3 , ch. $2, \S 3(1700-01)$ (Eng.) ("That no Pardon under the Great Scal of England be pleadable to an Impeachment by the Commons in Parliament."). The Act was mainly a series of similar minor adjustments of the balance of power between Parliament and the King. The connection between the Danby episode and the Act's pardon provisions is clear even though many years clapsed between the two. See Duker, supra note 10, at 496-97 \& n.110.

41. See Duker, supra note 10, at 496 \& nn.108-09.

42. See infra text accompanying notes 56-59. 
the possibility, it seems quite clear that they did not affirmatively intend selfpardons to be valid.

Most colonial proprietors and governors had broad pardon powers delegated by the Crown. ${ }^{43}$ In the immediate aftermath of the Revolution, all of the states restricted their executives' powers of pardon." Massachusetts, for instance, only allowed pardons after a criminal had been convicted."s Several states completely removed the power to pardon impeachments from their governors' purview. ${ }^{46}$ Georgia and New Hampshire took the power out of the hands of the Governor completely, giving it instead to the Legislature. ${ }^{47}$ These restrictions on the executive power are not surprising, given that the Americans had just fought a war against a monarchy.

The executive pardon power was thus somewhat moribund in America when it came time to write the Federal Constitution. The first two suggested structures for the new government, the Virginia and New Jersey Plans, omitted the pardon power altogether. ${ }^{48}$ Through the initiative of John Rutledge, the Committee of Detail added a pardon power based on the language of the Act of Settlement. This power covered federal crimes but could not preempt congressional impeachments. ${ }^{49}$

Soon after, the Convention changed the clause to exclude pardons that removed the penalties of impeachment after conviction by the Senate. ${ }^{50}$ This exclusion was both a constraint on the power of the President and a recognition of the limited impeachment power of Congress as compared to Parliament. The new Constitution limited the effect of impeachment and conviction to removal and disqualification from office." In England, by contrast, the penalty could also include imprisonment, forfeiture of property.

43. See Duker, supra note 10 , at 497-500.

44. See id at 500-01.

45. See id. at 500 . This restriction included, unlike in England. pardons to restore nghts after an impeachment. See id.

46. See id. at 500-01 (Delaware, Massachusetts, North Carolına, Pennsylvana, and Virgınıa)

47. See id. at 500 .

48. See Humbert, supra note 10, at 15 . One can only speculate as 10 why 11 was omilted Perthaps it was a mere oversight. Perhaps the drafters felt that such a power would not be worth much. gwen the federal criminal law's small purview at that time.

49. See id. The relevant text read: "He shall have power to grant repneves and pardons, but his pardon shall not be pleadable in bar of an impeachment." 2 THE RECORDS OF THE FEDERAL CONVENTIO OF 1787 at 185 (Max Farrand ed., 1911) (reprinting Madison's notes) (hereinafter Recoros) (emphasis added) Humbert and Blackstone interpret this as excepting only preimpeachment relief. See HLMBERT, supro note 10 , at 62 \& n.36 (citing 4 WiLlLAM BLACKSTONE. COMMENTARIES 398-99 (Wendell's ed . 1847)). For the language of the Act of Settlement, see supra note 40.

50. See supra text accompanying notes 11,45 . The language was changed to its current form "[H]c shall have Power to grant Reprieves and Pardons for Offences against the United States, except in Cases of Impeachment." U.S. CONST. ant. II, § 2, cl. 1; see 2 RECORDS. supra note 49. at 419-20. 599. see also HUMBERT, supra note 10, at 62 (discussing difference between "pleadable in bar of" language and more exclusive "in cases of" phrase).

51. See U.S. CoNST. ant. I, § 3. cl. 7. 
fines, exile, and sometimes even death. ${ }^{52}$ Given America's lighter punishment, postimpeachment mercy was not nearly as important.

There was little debate on the pardon power-only a few verbal exchanges and a couple of motions. ${ }^{53}$ Roger Sherman, distrustful of vesting a king-like power in the President, wanted to require the Senate's consent to pardons, but this proposal was overwhelmingly voted down.$^{54}$ Luther Martin suggested a Massachusetts-style ban on preconviction pardons, but withdrew the motion after James Wilson pointed out that pretrial pardons preempting prosecution might be needed to induce coconspirators to testify against their leader..$^{55}$ The presidential pardon power was emerging as more akin to the broad power of the King than the reduced or shared powers of the states' governors.

At that point, the debate turned to matters that more directly concerned the self-pardon issue. Using a Danby-like hypothetical, Edmund Randolph argued that pardons for treason should be excluded from the President's authority. ${ }^{36}$ Allowing the President to pardon treason, Randolph said, was "too great a trust. The President may himself be guilty. The Traytors may be his own instruments." ${ }^{57}$ James Wilson responded that pardons for treason could be very important and that the power was best placed solely with the President. ${ }^{58}$ Highlighting the distinction between Randolph's hypothetical and the Danby case, Wilson pointed out that "[i]f [the President] be himself a party to the guilt he can be impeached and prosecuted."59

Wilson's view carried the day; Randolph's motion was defeated by a vote of eight to two. ${ }^{60}$ The pardon power was thus set in its current form, with the

52. See Maurice Taylor Van Hecke, Pardons in Impeachment Cases, 24 MiCH. L. REv. 657, 659 (1926).

53. Some brief, minor discussion that had no bearing on the self-pardon question is omitted here, but can be found in 2 RECORDS, supra note 49 , at 626-27.

54. See id. at 419.

55. See id. at 426.

56. See supra text accompanying notes $32-41$. The extent to which the Framers were aware of the Danby case in unclear; it was never mentioned specifically in discussions of the pardon power. Nevertheless, the parallel seems too striking to ignore.

57. 2 RECORDS, supra note 49 , at 626 .

58. See id. at 626 . Alexander Hamilton, who had originally supported requiring Senate approval for treason pardons, see HUMBERT, supra note 10, at 15, later elaborated on the case for vesting the treason pardon power in the President. After admitting the possibility that the President might be one of the conspirators, Hamilton argued that a strong, centralized treason pardon power was needed nonetheless:

[I]n seasons of insurrection or rebellion, there are often critical moments when a well-timed offer of pardon to the insurgents or rebels may restore the tranquility of the commonwealth .... The dilatory process of convening the legislature, or one of its branches, for the purpose of obtaining its sanction to the measure, would frequently be the occasion of letting slip the golden opportunity.

THE FEDERALIST No. 74, at 449 (Alexander Hamilton) (Clinton Rossiter ed., 1961). Hamilton thus saw the pardon power as an instrument of good governance, as distinguished from the instrument of corruption it proved to be in the Danby case.

59. 2 RECORDS, supra note 49 , at 626 . Others spoke after the Randolph proposal, mainly discussing possible roles for the Senate in the pardon process. The final vote nevertheless reflects Wilson's view that the pardon power should include treason and should vest in the President alone. See id. at 626-27.

60. See id. at 627 . Connecticut was split and so its vote did not count on this motion. See id. 
exclusion of postimpeachment relief being the only formal adjustment from its English equivalent. When the question of potential presidential self-dealing through the pardon power had been raised, the response was decisive. Unlike the King, Wilson had argued, the President was not above the law. As such, the pardon power could not protect him as it had King Charles II.

\section{Original Intent}

The preceding Section represents the sum of the evidence from which one must deduce the Framers' intent. The self-pardon was nowhere mentioned in the debates or in the English history that informed them. As such, arguments derived from the intent of the Framers are speculative at best. There are two likely possibilities: Self-pardons either were not considered, or their invalidity was silently presumed. A third possibility, that self-pardons were presumed valid, is less likely.

\section{Oversight}

It is conceivable that the Framers simply failed to consider the possibility of self-pardons. The discussions on the pardon power represented, after all, only a few pages out of hundreds in the Convention debates. ${ }^{61}$ When Randolph suggested the possibility of presidential treason, his solution was to eliminate the treason pardon, not to prohibit self-pardons, which would have been a more direct solution. Randolph's scenario, a treasonous executive pardoning his treasonous lackeys, was similar to the Danby episode; perhaps his image of the pardon power came from seventeenth-century England as well. The status of the King as above the law meant that there was no such thing as a self-pardon. ${ }^{62}$ When contemplating a Danby-like situation, therefore, Randolph might have forgotten that the President was different. In other words, perhaps the self-pardon was just lost in the translation.

Wilson's response, however, took the difference between King and President into account. The President, Wilson reminded Randolph, could be impeached and prosecuted for his crime. Since the President was not above the law, a Danby-like situation in America would not leave the President immune from punishment. But how could a President be prosecuted if he could pardon himself? Perhaps Wilson made the implicit assumption that the President could only be weaker than the King; that the powers of the former were less than (or at most equal to) those of the latter. As such, it might not have occurred to Wilson that the President could have a new power.

61. See generally RECORDS, supra note 49.

62. See supra text accompanying notes $30-31$. 
If this was the case-if the continuity between the English and American pardon powers, coupled with the absence of self-pardons in the former, lulled the Framers into missing the possibility of self-pardons-then no positive answer to the self-pardon question can be found in the Convention debates.

\section{Implicitly Invalid}

In the discussion of treasonous Presidents trying to skirt the law, it seems likely that the possibility of a self-pardon occurred to one of the dozens of people in the room. Thus, a second explanation for the Framers' silence was that they presupposed a President could not pardon himself - that the illegality of self-pardons literally went without saying.

As mentioned above, James Wilson answered Edmund Randolph's concern of a "guilty" President by pointing out that the President could be prosecuted. While this response might have meant that Wilson was overlooking the selfpardon, or that he was confident that treasonous Presidents would restrain themselves, it more plainly might have stemmed from an assumption by Wilson that self-pardons were invalid and (as Wilson argued elsewhere) that Presidents could always be prosecuted. ${ }^{63}$ In other words, in Wilson's view, the pardon power did not place the President above the law.

Nobody objected to Wilson's interpretation by arguing, "That cannot be; the President in such a situation could just pardon himself and stay unpunished." Instead, the delegates voted without comment to centralize the pardon power in the President and to include the power to pardon traitors, secure in the knowledge that a President could be prosecuted by his successor.

\section{Implicitly Valid}

A third reading - that the Framers presupposed a President could pardon himself-is implausible but deserves to be addressed. When Randolph set out his scenario, according to this third reading, he was worried about the President's cronies going free, not the President himself going free. After all, the President could be impeached, while his subordinates might be unreachable; only "officers," whose appointments require Senate confirmation, are subject to impeachment. ${ }^{64}$ Furthermore, a President might choose not to pardon himself. He might choose to maintain his innocence and avoid the

63. On Wilson's belief that the President was not immune from prosecution in general, see Freedman, supra note 21, at 16, and William F. Allen, Note, President Clinton's Claim of Temporary Immunity, 11 J.L. \& POL. 555, 583-84 (1995), which mention Wilson's statements at Pennsylvania ratifying convention.

Another reading, that Wilson assumed any such President would be impeached before he could pardon himself, is implausible. Pretrial pardons were legal-Wilson had just convinced Martin to withdraw a motion that would have said otherwise. See supra text accompanying note 55. Thus a self-pardon could be issued instantly, well before the slow process of impeachment would have even begun.

64. See U.S. CONST. art. II, § 2, cl. 2; id. § 4. 
imputation of guilt carried by a pardon, it might not be worth the political costs, or he might be concerned about his place in history. Indeed, the fact that a President will weigh such considerations of politics and public opinion is a major reason for vesting the pardon power in him in the first place. ${ }^{\text {os }}$ Alternatively, the idea of a President malfeasing at that level may have been too unlikely to worry about. ${ }^{66}$

This reading of the Framers' intent is unconvincing. It seems more likely that Randolph did not consider self-pardons than that he had no objection to them. After all, if the possibility of pardoning his confederates was "too great a trust" for Randolph to repose in the President, why would the possibility of him pardoning himself (and for any crime, not just treason) not be even worse? Furthermore, it hardly seems that Wilson would have been able to assuage the Convention's fears by pointing out that a treasonous President could be prosecuted-only if he refused to pardon himself. Remember that treason was narrowly defined in the Constitution as "levying war" against the United States or "adhering" to its foes. ${ }^{67}$ Randolph's scenario was not one of mere political differences but of outright insurrection. If the delegates assumed the selfpardon was authorized, Wilson would have been asking the Convention to rely on a perfidious President's self-restraint, repentance, and willingness to suffer the penalty for treason even though he had the power to avoid it. If this was what Wilson meant, it seems doubtful that his argument would have carried the day. It is thus unlikely that the Framers recognized the potential for selfpardons but never mentioned them in their discussions of self-dealing pardons, or that their silence indicates a conscious acceptance of self-pardons as valid.

Ultimately, one can only speculate as to what the Framers thought about the self-pardon. Given the course of their debate, however, it is reasonable to conclude that they believed the power to be invalid, or at least that they did not think about it. Relying on the possibility of impeachment and prosecution to hem in the President, the Framers did not view the pardon power as placing the President above the law.

Exploring original intent is, of course, only one way of determining the meaning of the pardon power. The Constitution and government the Framers created provide more evidence that self-pardons are constitutionally disfavored.

\section{TEXT ANd Structure}

Article II, Section 2, Clause 1 of the Constitution states that the President "shall have Power to grant Reprieves and Pardons for Offences against the

65. See Charles J. Bonaparte, The Pardoning Power, 19 YALE LJ. 603.607 (1910) (discussing role of public opinion in determining pardon policies).

66. But see THE Federalist No. 74, at 448 (Alexander Hamilon) (Clinton Rossiter ed. 1961) (reflecting consideration of, and willingness to accept, risk of malfeasing Presidents)

67. U.S. CONST. art. III, $\S 3, \mathrm{cl}$. I. 
United States, except in Cases of Impeachment."68 The most recent major Supreme Court case on the pardon power, Schick v. Reed, ${ }^{69}$ stated that "the pardoning power is an enumerated power of the Constitution and ... its limitations, if any, must be found in the Constitution itself."70

At first glance, then, it might seem that the Supreme Court has read this clause as establishing a plenary power. The conventional reading of the pardon power does sound sweeping, and one could logically view it as including selfpardons. Indeed, this plain, broad reading is the most potent argument in favor of the legality of such a power. This Part of the Note explores and criticizes the simple reading, however, and suggests a different way of approaching the Constitution: structuralism. This alternate method provides a more complete and holistic view of the Constitution, and suggests that self-pardons are invalid.

\section{A. The Textual Approach}

There are two limits to the President's power explicit in the Pardon Clause. First, the power applies only to "Offences against the United States." S11 Second, "Cases of Impeachment" are excluded." The "simple" reading of the text points to these explicit restrictions and concludes that what is left, by the principle of expressio unius, is not restricted. ${ }^{73}$ If the President did not have the power to pardon himself, the expressio unius reading says, the Framers would have added "and cases involving himself." This Section argues, however, that such a reading is simplistic and inaccurate.

The first problem with this reading is that it is bound too tightly to the Pardon Clause itself. To properly understand constitutional provisions, it is almost always essential to read the clause in question against the background of the rest of the Constitution. Particularly instructive examples are those other clauses that, like the Pardon Clause, grant a power and carve out an immediate exception. Sometimes, the remainder of the Constitution will contain an explicit limitation. In each such case, then, the immediate exception is not the only limitation on the underlying power being granted.

68. Id. art. III, § 2, cl. 1 .

69. 419 U.S. 256 (1974).

70. Id. at 267. Earlier cases used even broader language. See, e.g., United States v. Klein, 80 U.S. (13 Wall.) 128, 147 (1871) ("To the executive alone is intrusted the power of pardon, and it is granted without limit."); Ex parte Garland, 71 U.S. (4 Wall.) 333, 380 (1866) ("The [pardon] power thus conferred is unlimited."). Note the language in Klein of entrusting, which hearkens back to Randolph's concerns of the power being "too great a trust." See supra text accompanying note 57 . The Court is thus arguing that the plain breadth of the text reflects a trust by the Framers that the power would not be abused.

71. U.S. CoNST. art. II, $\S 2$, cl. 1; see supra note 10 and accompanying text.

72. U.S. CONST. art. II, $\& 2$, cl. 1; see supra note 11 and accompanying text.

73. The full phrase is expressio unius est exclusio alterius (the expression of one thing excludes the other). 
Congress's power to raise and support armies has one exception mentioned next to it: Appropriations for the army must be for two years or less. ${ }^{74}$ But the remaining power to raise and support the army is not unlimited; the Third Amendment precludes Congress from supporing peacetime troops by quartering them in private homes without the owners' consent. ${ }^{75}$ Congress has the "Power to declare the Punishment of Treason," but the punishment cannot "work Corruption of Blood, or Forfeiture except during the Life of the Person attainted."77 Again, this exception does not render the remaining power unlimited; the Eighth Amendment requires that the punishment not be cruel and unusual. ${ }^{78}$ Finally, and significantly for those who would argue that the pardon power is unrestricted, it is arguable that presidential pardons are hemmed in by the Equal Protection Clause of the Fourteenth Amendment. ${ }^{70}$ While this Note does not argue that self-pardons are forbidden because of other explicit constitutional provisions as in the above examples, it does rely on reading the Constitution in a similarly holistic way.

The second problem with the "simple" reading is that it places too much reliance on the suspect maxim of expressio unius. Expressio unius arguments often prove too much; merely adding an exception immediately after a grant of power should not always be read as making the remainder of the power unlimited, even if there is no explicit external textual limitation. For instance, the Constitution dictates that each state's legislature shall appoint its presidential electors. The legislatures cannot, however, appoint a Senator, Representative, or holder of a Federal "Office of Trust or Profit." Does this exclusion of federal officials mean that the remaining power to appoint is

74. See U.S. CONST. art. I, $\S 8$, cl. 12. This stands in contrast to the nexl grant of power to Congress. concerning the navy, which is not similarly restricted. See td. $\mathrm{cl} .13$

75. See id amend. III.

76. Id. art. III, \& $3, \mathrm{cl} .2$.

77. $I d$.

78. See id. amend. VIII.

79. See Daniel T. Kobil, The Qualiny of Mercy Stramed: Wrestung the Pardoning Poswer from the King. 69 TEX. L. REV. 569, 617 (1991) ("If the President acted for racially discriminatony reasons and granted clemency to all white applicants for pardons, while denying clemency to all black applicants. the judictary could review and presumably invalidate such use of the clemency power on equal protection grounds ") Kobil argues that under current doctrine, presidential actions are subject to the equal protection requirement See id. at 617 n.305 (citing Bolling v. Sharpe, 347 U.S. 497, 500 (1954) (equal protectuon standards apply to federal government); Wayte v. United States, 470 U.S. 598, 607-09 \& n.9 (1985) (holding that federal prosecutorial discretion may not violate "ordinary equal protecuon standards")): see also Osbome Folmar, 735 F.2d 1316, 1317 (11th Cir. 1984) (holding that state pardons may be challenged on equal protection grounds).

This would be less of a constraint on the President than a ban on self-pardons, because there would be more flexible remedial options. That is, if a self-pardon is invalıd, the only remedy is to votd tt. On the other hand, if a pardon violates equal protection, then Congress, a subsequent President. or possibly even courts could extend it to the excluded class without voiding it. Cf. Yick Wo v. Hopkins. 118 U.S. 356 373-74 (1886) (choosing option of freeing victims of equal protection violation rather than option of voiding law under which they were prosecuted).

80. U.S. CONST. art. II, § I, cl. 2. 
plenary? Could a legislature appoint, say, a foreign potentate? Presumably not; there are other limits. ${ }^{81}$

Expressio unius readings are also suspect when they clash with implicit constitutional dictates. An example of this is the Elections Clause: "Congress may at any time by Law make or alter such Regulations [regarding the times, places, and manner of electing Senators and Representatives], except as to the Place of chusing Senators." ${ }^{12}$ The expressio unius reading of this clause would be that Congress can make any regulation it wants regarding the times and manner of choosing all members of Congress, and the places of choosing Representatives. The sole restriction-against regulating the places of choosing Senators-implies that the remaining power is plenary. Such a reading cannot be accurate. Congress presumably could not, for instance, restrict the "place" of all House elections to Point Barrow, Alaska, and force eligible voters to go there to exercise their suffrage. This would make voting too difficult, entrench incumbents, and prevent majoritarian means for punishing such conduct. But this limit is not to be found in the Elections Clause itself.

The Supreme Court has agreed that the expressio unius reading of the Elections Clause is the wrong one:

We see no reason to believe that the authority of Congress over federal election practices is of such a wholly different nature from the other grants of authority to Congress that it may be employed in such a manner as to offend well-established constitutional restrictions stemming from the separation of powers. ${ }^{83}$

81. It is worth noting that at other points in the Constitution qualifications for other offices specifically preclude similar appointments by requiring that officials such as Senators, see id. art. $1, \S 2$, cl. 2; Representatives, see id. § 3, cl. 3; and the President, see id. art. II, § 1, cl. 5, be citizens with long residence in the United States, and that they swear an oath or affimation to support the Constitution, see $i d$. art. VI, cl. 2. Other appointments have the procedural safeguard of Senate confirmation built in. See id. art. II, $\$ 2$, cl. 2.

82. Id. art. I, $\S 4$, cl. 1 .

83. Buckley v. Valeo, 424 U.S. I, 132 (1976) (holding that Congress's election-regulating power does not imply ability to appoint its own campaign regulators independent of President's appointment power). The Supreme Court has, however, used expressio unius readings in other contexts. See, e.g., U.S. Term Limits, Inc. v. Thornton, 115 S. Ct. 1842, 1850 \& n.9 (1995) (holding enumerated qualifications for members of Congress in Article I to be, by expressio unius, sole permissible qualifications); INS v. Chadha, 462 U.S. 919, 955-56 (1983) (using expressio unius reading of bicameralism and presentment requirement to forbid any but explicit exceptions).

Such uses of the maxim by the Court, however, have been controversial. See, e.g., Thornton, $115 \mathrm{~S}$. Ct. at 1886 (Thomas, J., dissenting) (criticizing majority's use of expressio unius); E. Donald Elliott, INS v. Chadha: The Administrative Constitution, the Constitution, and the Legislative Veto, 1983 SUP. CT. REV. 125, 140-43 (criticizing Chadha Court's use of expressio unius); M.B.W. Sinclair, Law and Language: The Role of Pragmatics in Statutory Interpretation, 46 U. PITT. L. REV. 373, 415 (1985) (defending maxim but admitting it has faced "most hostile antipathy"); see also THE FEDERALIST No. 83, at 496 (Alexander Hamilton) (Clinton Rossiter ed., 1961) (calling use of expressio unius-type argument "fallacy"). Even if these uses of the maxim by the Court are accepted, they are readily distinguishable from the uses detailed here. It is one thing for the Court to read the descriptions and enumerations of qualifications and procedures expressio unius, as an exclusive list; these things purport to be lists ("a Senator must be $\mathrm{X}, \mathrm{Y}$, and Z," "a bill is passed by doing A, B, and C"). It is quite another to use the maxim to render the grant of a power unlimited. 
In other words, the rest of the Constitution (including such implicit doctrines as separation of powers) cannot be ignored, even if a grant of power appears plenary at first glance. The presence of one exception, "the Places of chusing Senators," does not strengthen the remainder of the power to the point where it can offend the rest of the constitutional framework. ${ }^{g+}$

The above examples represent every instance where, as with the pardon, there is a constitutional grant of "power" with an explicit exception carved out alongside. It is clear that strange outcomes arise from reading grants of power expressio unius and from deeming contextual constitutional principles irrelevant. Anyone who feels uncomfortable with these extreme results must think twice before giving the pardon power a similar reading. The next Section will argue that, as with the foregoing examples, the pardon power should not be read expressio unius or without consulting the rest of the Constitution. Instead, the structure, themes, and principles of the Constitution must be examined to provide a complete reading of the pardon power.

\section{B. The Structural Approach}

In showing that one should be careful before reading clauses expressio unius, the examples recited above demonstrate that it is essential to examine the entire constitutional framework rather than just one clause in isolation. As the Court held in Schick v. Reed, ${ }^{85}$ the limits of the pardon power "must be found in the Constitution itself," not, notably, in the clause itself. ${ }^{86}$ This hints at a helpful method of constitutional interpretation-structuralism-which uses the overall structure of constitutional government as evidence for understanding individual parts of its design.

Looking at structure provides a more complete, less wooden reading of the Constitution than does the blunt textualism of expressio unius. Reading the Pardon Clause in isolation tells us nothing about what "power" means, what limits it does or does not have, or even what a "pardon" is. Structure answers these questions by examining more broadly the limits and bounds of the presidency and the government as they are defined by the Constitution. ${ }^{37}$

84. In a way, the broader readings of these clauses are stull expressio unus readings. they simply look for limits in the Constitution as a whole, not just the clause in question.

85. 419 U.S. 256 (1974).

86. Id. at 267; see supra note 70 and accompanying text. As this Note will argue in this Section, for something to be "in the Constitution" it does not need to be spelled out explicitly in the text. Concepis like the separation of powers, checks and balances, and. this Note will argue, disfavor for self-dealing. are implicit in the Constitution.

87. See BOBBIT, supra note 22, at 7 (describing structuralism and placing 1 within canon of interpretive methods). See generally CharLES L. BLACK. JR.. STRLCTLRE AND RElATIONSHIP IN CONSTITUTIONAL LAW 3-32 (1969) (suggesting greater use of inference from structure in constututional exegesis). Constitutional structuralists thus look at text and contexl. stressing the ways in which vajous provisions (explicit and implicit) interrelate. Instead of treatung the Constutution as a senes of disjointed, unrelated clauses, they treat it as a whole. looking to the structure of consututuonal government. stressing 
Looking at structure also fills in some of the inferential gaps left by the Framers' silence. While it is easy to lose sight of intent when parsing a single clause in a vacuum, it is harder to do so when reading the Constitution as a whole. ${ }^{88}$ This Section will argue that self-pardons are at odds with the structure of American constitutional government-in particular, with the structural imperative against self-dealing and with the limits of Article II-and are thus invalid.

\section{Self-Dealing and Self-Judging Outside of Article II}

The federal government is structured to prevent self-dealing, as evidenced by several constitutional provisions. A member of Congress, for instance, cannot simultaneously hold another federal office, and cannot resign to take a job that was created or whose pay was increased during that term of Congress. ${ }^{89}$ Congress cannot legislate a pay raise for itself that takes effect before the next congressional election, ${ }^{90}$ and the presidential salary cannot be increased without an intervening presidential election. ${ }^{91}$ The President also cannot receive any other "emolument" from the United States besides his salary. ${ }^{92}$ In other words, federal lawmakers cannot create or enhance plush, high-paying government jobs for themselves, at least not without letting the voters review the decision.

Another example is that the Chief Justice, not the Vice President, presides when an impeached President is tried. ${ }^{93}$ If this were not the case, the Vice President would have an undue interest in the outcome, since he would replace a convicted President. Especially since the Vice President originally could have

its internal consistency and recurring themes. See, e.g., Akhil Reed Amar \& Neal Kumar Katyal, Executive Privileges and Immunities: The Nixon and Clinton Cases, 108 HARV. L. REV. 701, 703 (1995) ("Even if the First Amendment did not exist, the Constitution's overall structure and its commitment to democratic self-government would require a broad freedom of speech and debate for citizens on issues of public concern.").

88. None of this should imply that there is only one way to read the Constitution's structure. Indecd, this Note will make several structural arguments and raise some structural counterarguments. In the end, though, this Note maintains that the most convincing readings are those that preclude self-pardons.

89. See U.S. CoNST. art. I, § 6, cl. 2; Atkins v. United States, 556 F.2d 1028, 1070 (Ct. Cl. 1977) ("This provision was generated out of a fear that corruption would result if the legislature multiplied the number or increased the salaries of public offices for the benefit of its own members.").

90. See U.S. CONST. amend. XXVII. This Amendment was initially proposed by Madison as part of the Bill of Rights, but was not approved until 1992. See Michael Stokes Paulsen, A General Theory of Article V: The Constitutional Lessons of the Tiventy-Seventh Amendment, 103 YALE L.J. 677, 678 (1993). Admittedly, two-thirds of the Senators could benefit from this pay raise before they faced reelection, but the majority party might be voted out of power in response to the pay raise.

91. See U.S. CONST. art. II, $\S 1$, cl. 7. The President is, of course, a required actor in the lawmaking process. This provision thus provides an important symmetry with the Twenty-Seventh Amendment in preventing quid pro quo pay raise deals. The President's salary also cannot be diminished during his term of office. See id.

92. See id.

93. See id. art. I, § 3, cl. 6 . 
been an adversary of the President, this self-interest and potential disloyalty would have posed a conflict. ${ }^{94}$

The structural distaste for self-dealing is found in broader constitutional contexts as well. Professor Akhil Amar has argued that the entire Bill of Rights was intended to prevent the federal government from self-dealing:

To borrow from the language of economics, the Bill of Rights was centrally concerned with controlling the "agency costs" created by the specialization of labor inherent in a republican government. In such a government the people (the "principals") delegate power to run dayto-day affairs to a small set of specialized government officials (the "agents"), who may try to rule in their own self-interest, contrary to the interests and expressed wishes of the people. ${ }^{95}$

Thus, without the Bill of Rights, a self-dealing Congress and President could control the press, take away guns, search houses, seize property, and jail people indefinitely, all in order to further their own interests at the expense of the will of the majority. ${ }^{96}$

Self-judging is an important subset of self-dealing. ${ }^{97}$ It also represents structural evidence that is analytically close to self-pardons. There are two such pieces of evidence implicit in the constitutional structure. ${ }^{98}$ The first concerns vice-presidential impeachments. The Constitution provides that the Vice President is the President of the Senate ${ }^{99}$ and that the Senate has "the sole power" to try all impeachments, ${ }^{100}$ but that when the President has been impeached, as discussed above, the Chief Justice of the Supreme Court presides over the trial. If we were to read these provisions expressio unius, then, the only time someone other than the Vice President would preside is when the President is on trial. But what about when the Vice President is being tried? If the Vice President cannot be trusted to preside over the President's trial, how can he be trusted to preside over his own? It would be quite odd if the Framers intended (and the Constitution required) this result. ${ }^{101}$ As with self-pardons, the accused would be acting as his own

94. John Adams's Vice President, for instance, was his foe Thomas Jefferson Jefferson had his oun troubles with his Vice President, Aaron Burr. See Matthew M. Hoffman. The Illegtimute Presudent Minority Vote Dilution and the Electoral College, 105 YALE L.J. 935.945 n.33 (1996). This uncomfortable situation was changed in 1804 by the Twelfth Amendment, which made tI easier for Presidents to select their own Vice Presidents and run as a single ticket. See U.S. CONST. amend. XII.

95. Akhil Reed Amar. The Bill of Rights as a Constuution, 100 YALE LJ 1131. 1133 (1991)

96. See generally Amar, supra note 95 .

97. See infra Subsection IV.B.1.

98. As in the previous Section on expressio unius arguments, It cannot be formally proven that esthes of these implicit pieces of evidence are directly mandated by the Constututuon. Nevertheless. ignonng them causes odd results that anyone accepting self-pardons must confront.

99. See U.S. CONST. art. I $\$ 3, \mathrm{cl} .4$.

100. See id. cl. 6.

101. See Akhil Reed Amar \& Vikram David Amar, Is the Presidential Succession Law Consurutional?. 48 STAN. L. REV. 113, 122 n.59 (1995) (stating that Vice Presidents cannol preside at their own 
quasi-judge..$^{102}$ Indeed, the presidential case follows a fortiori from the vicepresidential example. The Vice President is only presiding over the impeachment trial, whereas the Senators are the ultimate decisionmakers; the President exercising the pardon power, by contrast, is both quasi-judge and quasi-jury. ${ }^{103}$

The other implicit constitutional prohibition against self-judging comes from the Expulsion Clause, which provides that either chamber of Congress can expel its members by a two-thirds vote. ${ }^{104}$ Although there is no explicit prohibitory language in the Clause against voting in one's own expulsion case, members of Congress do not do so, despite the high stakes and narrow margins of many expulsion votes. ${ }^{105}$

In other parts of the Constitution, then, government officials are kept from acting as decisionmakers in matters that directly, materially, and uniquely affect them. This disfavor for self-dealing in the structure of the government, explicitly recognized by the Framers themselves, ${ }^{106}$ provides important structural support for the claim that a President is forbidden from pardoning himself. ${ }^{107}$

impeachments). The text makes no provision for someone other than the Vice President to preside at his own impeachment. According to the Constitution, the President pro tempore only presides over the Senate when the Vice President is absent or when he is acting as the (Article II) President. See U.S. CoNST. art. I, $\S 3, \mathrm{cl} .5$.

102. I say "quasi-" because neither impeachments nor pardons are judicial acts. Impeachments are closer, however, involving as they do an "indictment" by the House (corresponding to a grand jury) and a "trial" by the Senate (corresponding to a petit jury, with the Vice President as the presiding judge). See U.S. CONST. art. I, $\S 2$, cl. 5 ; id. $\S 3$, cl. 6.

103. In exercising the pardon power the President is preempting or undoing the decisions of juries and judges, and hence his actions have a fully judicial scope. A regular prosecutor, on the other hand, can only preempt, not undo the work of courts.

104. See U.S. CONST. art. I, § 5, cl. 2.

105. See, e.g., 7 ANNALS OF CONG. 44 (1797) (expulsion of Sen. Blount of Tennessee); 9 ANNALS OF CONG. 2959-73 (1799) (unsuccessful expulsion of Rep. Lyon of Vermont); 17 ANNALS OF CONG. 324 (1808) (unsuccessful expulsion-by one vote-of Sen. Smith of Ohio); 126 CONG. REC. 28,977-78 (1981) (expulsion of Rep. Myers of Pennsylvania); see also 125 CONG. REC. 21,297-98 (1979) (vote to table expulsion of Rep. Diggs of Michigan). Significantly, Diggs did vote "present" on his censure the following day. See id. at 21,592. Given the implicit nature of this evidence and the surprising lack of litigation over it, this early and consistent congressional practice is the most authoritative constitutional interpretation we have.

It does not appear that anyone has argued that members of Congress technically could constitutionally vote on their own expulsions. In Powell v. McCormack, 395 U.S. 486, 510 n.30 (1969), the Supreme Court contrasted exclusion to expulsion and noted that in the latter, the defendant could speak on his own behalf. Pointedly absent is any mention of the advantage in expulsions (as opposed to exclusions) of voting on one's own behalf.

106. See, e.g., THE FEDERALIST No. 51 (James Madison) (Clinton Rossiter ed., 1961) (explaining separation of powers as intended to prevent self-dealing).

107. It could be argued, of course, that the existence of these explicit prohibitions against self-dealing makes it unlikely that there would be prohibitions like the self-pardon that are implicit. There are three arguments against such a reading. First, as argued in Part II, supra, the Framers did not affirmatively intend to allow self-pardons. Second, the analogous, explicit provisions forbidding self-dealing almost all appear in Article I, which is generally more detailed and leaves less unsaid than Article II. Third, there are plenty of examples of implicit constitutional prohibitions in addition to those, like vice-presidential impeachment, mentioned above. To take just one example, the First Amendment specifically forbids only Congress from 


\section{Article II and the Presidency'}

Even though the pardon power of the President resembles that of the King, the office of the President is in general much more limited. The specific bounds and nature of presidential power provide further structural evidence against self-pardons.

\section{a. Limited Terns}

While a King is King until he dies, a President is only President for four years at a time. ${ }^{108}$ The implicit self-pardon that comes with a King's sovereign immunity is backed up by his continued power as monarch. A presidential self-pardon, by contrast, would only be plunder to take home after a career-ending disgrace, even if an impeachment and conviction have stripped the President of all of the other badges and incidents of his former station. It thus seems a curious power to bestow.

This relates to an important power that Congress has over Presidents: its power to provide for them after they have left office. Through its standard legislative authority, Congress is in charge of providing for ex-officials, granting them pensions, resources, and the like. By disqualifying disgraced officials from "enjoy[ing]" federal office and its fruits, Congress's impeachment power can strip officials of these benefits. It can exercise the impeachment power even after an official has left office. "10

An impeached, self-pardoned President, however, "enjoys" his self-dealt immunity from prosecution. There is nothing that Congress, or the new President for that matter, can do about it. A self-pardoning President is thus the only federal official who can deal himself a fruit of his office and enjoy it after he is gone," indeed, even if he resigns but is impeached anyway and stripped of every other one of his benefits. Self-pardons thus clash with the constitutional structure of the limited presidency.

infringing on free speech. Does this mean that it is acceptable for the President to infnnge free speech by executive order? Presumably not.

108. See U.S. CoNST. art. II, § 1, cl. 1 (defining terms as four years in length): see also id. amend. XXII (limiting Presidents to two elected terms).

109. U.S. CONST. art. I, $\$ 3, \mathrm{cl} .7$.

110. See, e.g., Edwin Brown Firmage \& R. Collin Mangrum. Removal of the President: Resignatron and the Procedural Law of Impeachment, 1974 DUKE L.J. 1023, 1089-94 (discussing potential of impeaching Nixon even though he had already resigned): Hugh C. Macgill. The Nexon Pardon: Limis on the Benign Prerogative, 7 CONN. L. REV. 56, 62 (1974) (statung that Congress could sull impeach Nixon to take away his pension). The Constitution defines the punishment for impeachment as including disqualification from ever holding federal office, which would affeet an ex-President. See U.S. CoxST. an. I, § $3, \mathrm{cl} .7$.

111. Other federal officials can enjoy immunity from federal prosecuuon after their term of service. but they are enjoying a gift from the President, not a benefit of their office per se. What makes a selfpardon objectionable is that it is a self-dealt fruit of power. 


\section{b. The President as Chief Prosecutor}

The pardon power is tied structurally to the President's position as the nation's chief prosecutor. At first glance, this provides structural support for self-pardons. The President controls who is and is not prosecuted, and can back up that power by pardoning anyone who is prosecuted. Since the President can easily refrain from prosecuting himself, why not extend this ability to self-deal to pardons?

The answer is that a pardon does not correspond exactly with a decision not to prosecute; it is much more extensive and permanent. ${ }^{112}$ When a President leaves office, his successor can usually pick up a neglected prosecution, but he cannot "un-pardon" someone. Since a President would presumably never prosecute himself, ${ }^{113}$ he is never in any jeopardy if he can pardon himself.

Viewing this from another angle is instructive. To go free, a defendant who feels he has been unjustly accused has to convince one of the following of his innocence: a prosecutor, who can refuse to prosecute; a grand jury, which can refuse to indict; a judge, who can dismiss a case or sentence the convict lightly; a petit jury, which can acquit; or a President, who can pardon. If an accused President could not convince any of those five (presuming the President in the equation is his successor), why should he be able to go free? $\mathrm{He}$ would be the only person in America with the power to avoid jail solely by his own decision. We do not think twice about preventing prosecutors, judges, or jurors from handling their own cases. ${ }^{114}$ Structurally, why should the President be different?

A potential response is that unlike federal prosecutors, judges, and jurors, the President faces election. Indeed, that is one of the prime reasons for giving him the pardon power in the first place: He has to answer publicly for his decisions. ${ }^{115}$ But a self-pardon would most likely be issued by a President at the end of the line (e.g., Bush) or with little political capital left (e.g., Nixon). Nixon was not eligible to serve a third term, and would have resigned

112. A decision to refrain from prosecution would be permanent if the statute of limitations ran out before a new President took office. A swift impeachment would, however, eliminate this problem.

113. Special prosecutors (also known as independent counsel) change this equation somewhat-indeed, that is the reason for them. Of course, if push comes to shove, a President can refuse to appoint the special prosecutor, if he is willing to expend the necessary political capital. See generally 28 U.S.C. \$ 592 (1994) (granting Attomey General discretion in appointment of independent counsel). As discussed in the next paragraph, the self-pardon clashes structurally with the Constitution even if there is a special prosecutor.

114. While this is not explicitly stated in the Constitution, it is surely an implicit and important "background" principle informing any reading of the Constitution. See infra Subsection IV.B.1. Of course, in practice, recusal standards for all of these officials extend beyond the officials themselves to include family members and business partners. This Note does not, however, reach these less extreme cases as they relate to pardons.

115. See Bonaparte, supra note 65 , at $607-08$ (explaining sensitivity to public opinion as reason to vest sole power to pardon in President). 
anyway, ${ }^{116}$ and Bush had already lost his bid for reelection. ${ }^{117}$ By contrast, an accused President with enough political capital to avoid impeachment, keep the special prosecutor at bay, and get reelected would have no need to pardon himself (e.g., Clinton in his first term). In other words, the only President who would pardon himself is one with nothing to lose; the political check is thus rendered irrelevant.

Structurally, then, self-pardons fit uncomfortably with the regular political and separation of powers constraints operating on the President as chief prosecutor. The President's ability to refrain from prosecuting himself is counterevidence, to be sure, but it is readily distinguishable.

\section{Counterargument: The Moomess Question}

The case of President Bush raises another structural counterargument to the claim of illegality. Bush pardoned his alleged partners in the Iran-Contra scandal ${ }^{118}$ in what some saw as an effor to derail the investigation before it got to him. ${ }^{119}$ Whatever Bush's intent, that was the effect of the pardons; Special Prosecutor Walsh gave up because his mandate had been slashed. ${ }^{20}$

If a President can protect himself merely by pardoning his confederates, as King Charles II did, this would amount to a constructive self-pardon. Structurally, if a President can achieve a self-pardon by different ends, it would make sense that he could just do so directly. That is, one could argue that there would be no point in banning direct self-pardons if a President could legally construct an indirect one.

But Bush's actions did not amount to a self-pardon. Indeed, Bush was still in trouble after the pardons. He was left as the only major Iran-Contra figure who was not immune from prosecution; Walsh declared as much immediately after the pardons were issued. ${ }^{121}$ Furthermore, Bush's pardons meant that his associates would have been required to testify against him at any federal trial-because they were immune from prosecution, they could not invoke the Fifth Amendment and refuse to testify. ${ }^{122}$ Bush was thus going out on a

116. See supra text accompanying note 1 .

117. See supra text accompanying notes 3-8. Unlike Nixon. Bush was being succeeded by an opponent, not a hand-picked successor; if he wanted a pardon he had to get it from humself The checks on Bush were thus personal, not political: Bush cared about his place in history. and more particularly his personal image. See Schorr, supra note I (attributung to Bush vew that self-pardon Hould be "the coward's way out"). $56-57$.

118. This was reminiscent of Edmund Randolph's hypothetucal. See supro text accompanyıng notes

119. See Bensky, supra note 6; Garry Wills. Bush's Shameless Finale. WASH. POST. Dec. 27, 1992. at $\mathrm{Cl}$. This was also reminiscent of the actions of King Charles Il. See supro text accompanyıng notes $32-41$.

120. See Friedman, supra note 8.

121. See id.; see also Yost, supra note 3.

122. Precisely as James Wilson argued, pretrial pardons can be used to force coconspirators to testify against their leader. See supra text accompanying note 55 . 
limb; a self-pardon would have given him significantly more protection. In the end, Bush's gamble paid off, but for political, not constitutional reasons. ${ }^{123}$ His actions thus did not represent an indirect self-pardon.

Nixon's case presents another potential mootness argument. If a President can resign and have his successor pardon him, would this not amount to a constructive self-pardon? The facts of the Nixon case suggest otherwise. Nixon had not induced or made any deal with Ford to pardon him; Nixon had absolutely no leverage. ${ }^{124}$ When Ford issued the pardon, he did so at great political cost: "Possibly no single presidential act in recent years caused as much uproar as former President Gerald Ford's decision to pardon Nixon for Watergate." 125 The pardon probably cost Ford the election in $1976 .{ }^{126}$ In other words, Ford's action was a considered policy judgment just like any other conventional pardon, and not a go-for-broke, corrupt self-pardon. There is little reason to believe that any similarly disgraced President would have more political capital than Nixon did. Thus the structural counterargument of mootness is very weak at best. ${ }^{127}$

\section{Counterargument: The President Has "Suffered Enough"}

The Nixon and Bush examples show that not every President in a position to issue a self-pardon would do so, even if such a thing were constitutional. We have also seen that the pardon power cannot reach private civil and state criminal liability. Furthermore, impeachment ${ }^{128}$ and infamy would still face

123. As one contemporary source put it:

Walsh has ruled out, as pointless, suggestions that he compel former Defense Secretary Caspar

Weinberger to testify before a grand jury about what Bush knew. . .

Forcing Weinberger to testify "would only raise hell because it would seem to be vindictive, and that would give help to those who are opposed to having an independent counsel" ....

Friedman, supra note 8 (quoting unnamed "source, who has worked closely with Walsh").

124. This point has been convincingly argued by historian Stephen Ambrose. See, e.g., Stephen E. Ambrose, Why Didn't Nixon Burn the Tapes and Other Questions About Watergate, 18 NovA L. REV. $1775,1780-86$ (1994).

125. A Life of Greatness, Tragedy, CinCINNATI POST, Apr. 23, 1994, at 1 A.

126. This is widely believed, but of course difficult to prove conclusively. See, e.g., Kobil, supra note 79, at 617 (arguing that Nixon pardon "undoubtedly played a role" in Ford's defeat).

127. A more radical scenario, in which the Vice President is also a conspirator, might amount to a constructive self-pardon. If, say, President Nixon and Vice President Agnew robbed a bank, Nixon could pardon Agnew, resign, and then Agnew could pardon Nixon. Under the Twenty-Fifth Amendment, Nixon might not even have to resign-he could transfer power temporarily to Agnew, get pardoned, retake his power, and return the favor.

One likely response might be to forbid this as an invalid constructive self-pardon, though alternatively it might be valid, since neither man would really have been the judge in his own case. This Note does not reach that question though the former response seems more appropriate. At any rate, our hypothetical Nixon and Agnew could both face impeachment and possible prosecution for their comupt actions. See infra notes 128-29.

128. See supra text accompanying notes 11,59 . The inherent cormuption that would likely underlie a self-pardon would itself provide an additional, independent ground for impeachment, even if the courts were to rule that self-pardons are valid. It is well established that the phrase "high crimes and misdemeanors" includes comupt official acts, even if not unconstitutional or criminal, as grounds for impeachment. See 
any malfeasing President regardless of a self-pardon. ${ }^{129}$ Indeed, one of the reasons President Ford gave for pardoning Nixon was that Nixon had "suffered enough" already. ${ }^{130}$ Given all of these obstacles and penalties that a disgraced President faces, what harm is there in allowing self-pardons? Why, one might ask, should we read all of the above structural arguments into an otherwise straightforward text to achieve minimal gains?

Aside from the reply that these structural arguments should be incorporated because they are persuasive, one answer is that none of these additional punishments and penalties would necessarily apply, and thus the President might not have "suffered enough." The President's crime could be one that does not realistically expose him to any state prosecution (e.g., Watergate, Iran-Contra, Whitewater, and the Paula Jones case) or private civil liability (e.g., Watergate, Iran-Contra, and Whitewater). The underlying crime might be too minor to justify impeachment. ${ }^{131}$ As for "infamy," the President could

RAOUl BERgER, IMPEACHMENT 62-63 (1973); LAURENCE H. TRIBE, AMERICAN CONSTIUTIONAL LAW $\$$ 4-17, at 291 (2d ed. 1988); Dagmar S. Hamilton, Barbara Jordan. Constiultonal Lamer. 5 TEX J WOMEN \& L. 153, 155 (1996); see also THE FEDERALIST No. 65. al 396 (Alexander Hamilion) (Clinton Rossiter ed., 1961) ("The subjects of [an impeaching Congress's] junsdictson are those offenses which proceed from the misconduct of public men, or, in other words, from the abuse or volation of some public trust."). Note the reappearance of the language of "trust." See supra text accompanying notc 57. supra note 70.

The counts of impeachment against Nixon that had been voted out of the House Judiciary Commutec included such noncrimes as "endeavoring to misuse the Central Intelligence Agency." and "distegard of the rule of law" by "knowingly misus[ing] the executve power." H.R. REP. No. 93-1305, at 2,4 (1974) Each count accused Nixon of acting "in a manner contrary to his trust as President and subversive of constitutional government," id. at 3-4, thus using yet agan the language of "trust "Notably, one of the counts of impeachment against Andrew Johnson was "'comptly us[ıng] the pardoning power '” Duker. supra note 10, at 525 n.258 (quoting CONG. GloBE, 39th Cong.. 2d Sess. 320 (1867))

The fact that a President is exercising a presidential pouer does not immunize his corruption One can imagine, for instance, a case in which a President is impeached for veloing a bill in exchange for a bribe. In other words, it would not be the self-pandon that is impeachable. but the corruption underlying it.

129. Potential checks on the President can possibly even be taken a step funther-a self-pardoner arguably could be exposed to criminal prosecution for public misconduct. See supra note 21 As with impeachments, see supra note 128 , the fact that an act is not unconslitutional does not mean il cannot be criminalized. Obviously, most crimes have little connection to the Constıtution pes se. Thus, even if. arguendo, self-pardons are not void under the Constitution they might sull be punished criminally As with the example of the bribe-for-a-veto, the crime is not the pardon but rather the corruption underlyıng tt. which could be prosecuted as obstruction of justice, official misconduct, or perhaps even a self-bnbe

The fact that a President could be subject to such federal prosecution might be seen as a reason not to worry about self-pardons. Alternatively, though, it can be taken as a reason to vew self-pardons as standing on shakier ground than other pardons. If Congress tned to prosecute a President for pardoning others, the President would have a firm constitutional basis for defending his action as per se reasonable. absent blatant misconduct like accepting a bribe in exchange for grantung the pardon. A self-pardon. by contrast, would be easier to classify as presumptively unreasonable and corrupt.

A President could not pardon himself for the crime of pardoning himself. Even if the underlying crime were unreachable after a self-pardon (again assuming the pardon's valıdity arguendo), the cnme of self-pardoning itself would always be fair game. A pandon only reaches those acts a pardonec has already done. See supra note 12 and accompanying text. The President could keep issuing as many retrospective pardons as he wanted, but the last one he issued before leaving office would expose him to prosecution.

130. 32 CONG. Q. 2455 (Sept. 14, 1974) (Iranscnpt of Ford's statement accompanying pardon of Nixon).

131. Actually, Congress could probably impeach a President for anything. as long as it musters the requisite votes, since it has wide discretion in matters conceming impeachment and the subsequent tral 
pardon himself (assuming for the sake of argument the validity of such an act) in a way such that nobody would know what he had done. He could offer a mass amnesty ${ }^{132}$ that, unbeknownst to the public and posterity, included himself. ${ }^{133} \mathrm{He}$ could also pardon himself for a series of relatively minor crimes (e.g., covering up Watergate) and use general language that simultaneously pardoned him for more heinous, undiscovered crimes (e.g., treason), ${ }^{134}$ thus sparing himself at least some potential dishonor on the sly.

Furthermore, even apart from these hypothesized situations, the President would face all of these other penalties whether or not he pardoned himself. There is no reason to give him an unwarranted constitutional bonus. To reuse an earlier analogy, would we let a Vice President preside at his own impeachment if he were susceptible to state prosecution? Even with all of the penalties, legal and political, that face a malfeasing President regardless of a self-pardon, the problems of serious self-dealing, self-judging, and structural incongruities remain. If there is a valid reason to grant such a bonus, the successor President is better placed structurally to make that decision.

The purported power of a President to pardon himself would be constitutionally anomalous and unprecedented in the constitutional structure. Such a power simply does not fit with the rest of the structure of the government established by the Constitution. It clashes with other established provisions in the Constitution that prevent self-judging and self-dealing. It does not fit with the bounds of presidential prosecutorial and political power. One might prefer the simplicity of the narrow, expressio unius reading of the pardon power, allowing self-pardons, but upon further investigation it is shallow and unconvincing.

See Nixon v. United States, 506 U.S. 224 (1993) (holding question of procedure at federal judge's impeachment trial not justiciable). This broad authority stems from the seemingly plenary grant to Congress of "sole" authority in these matters. See U.S. CoNST. art. I, § 2, cl. 5; id. \& 3, cl. 6.

The Nixon Court held that the issue was a political question, and thus not justiciable, because the Constitution delegates the impeachment power to Congress and because there are no "discoverable" or "manageable" standards by which the Court could prescribe congressional conduct. Nixon, 506 U.S. at 228-29.

On its face, Nixon would seem to suggest a similar disposition awaits any self-pardon case. There is, however, strong reason to think otherwise. In a thoughtful concurrence exploring the limits of the political question doctrine, Justice Souter wrote:

One can, nevertheless, envision different and unusual circumstances that might justify a more searching review of impeachment proceedings. If the Senate were to act in a manner seriously threatening the integrity of its results, convicting, say, upon a coin-toss, or upon a summary determination that an officer of the United States was simply "a bad guy," judicial interference might well be appropriate. In such circumstances, the Senate's action might be so far beyond the scope of its constitutional authority, and the consequent impact on the Republic so great, as to merit a judicial response ....

Id. at 253-54 (Souter, J., concurring) (emphasis added) (citation omitted). Furthermore, the Supreme Court has explicitly recognized that the pardon power is not unlimited. See infra notes 136-39 and accompanying text.

132. See supra note 14 and accompanying text.

133. This possibility is explored in Parham \& Ferris, supra note 7.

134. See, e.g., supra note 15 (quoting Ford's general language pardoning Nixon). 


\section{CASE LAW}

Even though there has not yet been a litigated case concerning this issue, there are several cases that suggest the courts have had structural intuitions similar to those for which this Note has argued. This Part examines the case law and finds that it dictates that the pardon power is not completely plenary. Principles in the case law against self-judging and in favor of placing no person above the law are prominent. For these reasons, there is sufficient prudential basis for holding that self-pardons are illegal as a matter of Supreme Court precedent.

The leading and most recent Supreme Court case on the bounds of the pardon power is Schick v. Reed, ${ }^{135}$ which held that

the draftsmen of Art. II, $\S 2$, spoke in terms of a "prerogative" of the President, which ought not be "fettered or embarrassed." In light of the English common law from which such language was drawn, the conclusion is inescapable that the pardoning power was intended to include the power to commute sentences on conditions which do not in themselves offend the Constitution .... ${ }^{136}$

This case extended the pardon power to allow a particular condition. ${ }^{137}$ In doing so, however, the Court recognized that the power, while very broad, is not quite plenary. ${ }^{138}$ In contrast to earlier cases, which concentrated on text, ${ }^{139}$ Schick used the structural, holistic argument that even an apparently

135. 419 U.S. 256 (1974).

136. Id. at 263-64 (emphasis added). Schick is good law for the broader proposition cited here-that the pardon power is not plenary and is limited by the rest of the Constutution-and it remanns the leading case on the pardon power. See, e.g., Kass v. Reno. 83 F.3d 1186. 1193 (10th Cir. 1996) (using "does not offend the Constitution" standard); Virgin Islands v. Gereau. 592 F.2d 192. 195 (3d Cir 1979) (same). Carchedi v. Rhodes, 560 F. Supp. 1010, 1014 (S.D. Oho 1982) (statung that Schuck dictates pardon power is "almost absolute") (emphasis added).

137. Specifically, Schick approved a pardon commutung a death sentence to life in prison. condituonal on the ineligibility of the inmate for parole. See 419 U.S. al 257. See generally supra note 19 (addressing conditionality).

138. In the cases with sweeping language cited supra note 70 . the Coun was only commenung on the breadth of the pardon power in the context of its imperviousness 10 encroschments by the legisialive branch. See United States v. Klein, 80 U.S. (13 Wall.) 128, 147-48 (1871); Ex purte Garland. 71 U S it Wall.) 333, 380 (1866); see also United Stales v. Soeder. $120 \mathrm{~F}$ Supp 594, 596 (ND D III 1954) (forbidding legislative or judicial encroachment). While the accompanying dicta sound swecping. theit language falls in the face of the clear limit expressed in Schick. The Court simply neser had a case dealing with a pardon that was so unreasonable that it required limitung language For a helpful exposition of this type of distinction by Justice Souter regarding impeachment proceedings, see supra note 131

While Schick was only limiting the Presideni's power to impose condiuons on pardons. any limut is a step back from the sweeping language of previous cases. In addition. Schick explicitly contined the limits on the pardon power to that which "offend[s]" the Constitution. 419 U.S. at 264: this is consistent with the earlier cases' use of the doctrine of the separation of powers (a docinne which ean hardly be said to "offend" the Constitution that produced it) to bolster the pardon power, see Kletn. 80 U S (13 Wall) at 147-48; Garland, 71 U.S. (4 Wall.) at 380.

139. See supra note 70 . 
unrestricted power cannot be read as doing violence to the rest of the Constitution.

This leaves, of course, the question of which variations on the pardon power would "offend the Constitution" within the meaning of Schick. ${ }^{140}$ To answer this question, it is necessary to examine some key cases in the development of pardon power jurisprudence. Following that analysis, this Part turns to an examination of cases that establish in numerous other contexts the "offensiveness" of self-judging and flouting the rule of law.

\section{A. From Mercy to Public Policy: The Pardon Cases}

In the waning years of his tenure, John Marshall offered this exposition on the nature of the pardon power:

As this power had been exercised from time immemorial by the executive of that nation whose language is our language, and to whose judicial institutions ours bear a close resemblance; we adopt their principles respecting the operation and effect of a pardon, and look into their books for the rules prescribing the manner in which it is to be used by the person who would avail himself of it.

A pardon is an act of grace, proceeding from the power entrusted with the execution of the laws.... ${ }^{141}$

Marshall thus hearkened back to the English monarchical version of the power. Calling the pardon "an act of grace" makes the power sound royal and plenary. It also, admittedly, casts some doubt on the interpretation of the Framers' intent as injecting concepts of due process and the rule of law into government to replace the fiat of the King.

In Biddle v. Perovich, ${ }^{142}$ however, Oliver Wendell Holmes supplanted Marshall's account with one that "provide[s] a more solid base"143 for the pardon power:

We will not go into history, but we will say a word about the principles of pardons in the law of the United States. A pardon in our days is not a private act of grace from an individual happening to possess power. It is a part of the Constitutional scheme. When

140. Blatantly racially discriminatory pardons could be limited by the Schick standard. See Schick, 419 U.S. at 264; see also supra note 79 . Other than showing that the pardon power is not as plenary as it first appears, however, this does not answer the self-pardon question.

141. United States v. Wilson, 32 U.S. (7 Pet.) 150, 160 (1833) (emphasis added). Wilson held that the would-be recipient of a pardon could refuse to accept it. See id. at 161 .

142. 274 U.S. 480 (1927).

143. Duker, supra note 10 , at 509. 
granted it is the determination of the ultimate authority that the public welfare will be better served .... ${ }^{144}$

Holmes quite consciously contradicted Marshall's specific language. ${ }^{\text {is }}$ Instead of emphasizing the American pardon power as part of an unbroken tradition from England, Holmes recognized that America was different. The pardon power, he suggested, should be read structurally, as "part of the Constitutional scheme." 146 If pardons are an act of grace, they are an act of public grace, not private fiat.

It is Biddle's language of structure and policy, not Wilson's language of royalist benevolence, that Schick reflected when it limited the pardon power to those acts that are compatible with the rest of the Constitution. The law, then, is that the pardon power is intended to serve the "public welfare," not the corrupt whim of a self-serving executive. With that theme in mind, and with the structural Schick test forbidding those exercises of the pardon power that offend the Constitution, this Part now turns to an examination of cases on selfjudging and the rule of law, which show that these two categories, implicated directly in self-pardons, are germane to the Schick standard.

\section{B. Venerable Principles}

Self-pardons arguably fail the Schick test purely by dint of their selfdealing, justice-flouting nature discussed above. ${ }^{147}$ Two other principles, the rule of law and the unacceptability of self-judging, add further weight to the constitutional case against self-pardons. We have seen that the presidential pardon power is broad, ${ }^{148}$ certainly broad enough to withstand the invocation of mere platitudes couched in constitutional language. But we have also seen that a self-pardon is a particularly heinous example of self-judging and violating the rule of law. One should keep this in mind when exploring the cases described below. Although these cases concern players of much less consequence than the President and powers of much less breadth than the

144. Biddle, 274 U.S. at 486 (emphasis added). Biddle held that the secipient of a pardon commutung a death sentence could not refuse to accept it. See id. at 486-87. While not formally orcmuling Wilson. Biddle's holding is clearly at odds with the earlier case, and Holmes's choice of language is stnkingly adverse to Marshall's.

145. The Biddle Coun did not officially overrule Wilson's language of grace. possibly because It did not want to topple a venerable John Marshall opinion loudly if it could do so sub stlentio.

146. Biddle, 274 U.S. at 486.

147. See supra Section II.B. Self-dealing is not covered in this Part. While there are prohibitions against self-dealing in such common law concepts as fiduciary dutses, there is only one case that even dimly illuminates constitutional self-dealing principles. See Aduns v. United States, 556 F.2d 1028, 1070 (Ct. Cl. 1977) (stating that constitutional prohibitions aganst congressional self-dealing were intended to prevent comption).

148. See supra notes $12-19$ and accompanying text. 
pardon, they also concern acts of much less violence to our constitutional system of government than a self-pardon.

\section{Self-Judging}

One of the earliest cases in Supreme Court history, Calder v. Bull, ${ }^{149}$ illustrates the deep roots of disfavor for self-judging in Anglo-American law: "[Regarding] a law that makes a man a Judge in his own cause ... [i]t is against all reason and justice, for a people to entrust a Legislature with SUCH powers; and, therefore, it cannot be presumed that they have done it."150 Justice Chase's inclusion of this powerful presumption against self-judging so soon after the Constitution was written is telling. ${ }^{151}$

Similarly, the Federalist Papers, in their exposition of the new Constitution and the system it proposed to establish, offer evidence of the importance of this principle. In the famous Federalist No. 10, Madison wrote that "No man is allowed to be a judge in his own cause, because his interest would certainly bias his judgment, and, not improbably, corrupt his integrity." 152 The constitutional structure of the new Union was designed to prevent such pitfalls. ${ }^{153}$

Almost two centuries later, the presumption remains a powerful one in defining the restraints inherent in the structure of American constitutional government. To take just one particularly relevant example, the D.C. Circuit, in a recent case involving special prosecutors, recognized that "where the alleged criminal conduct of high level officials is involved, [executive enforcement discretion] must bow to the fundamental principle that no man can be a prosecutor or judge in his own case."154

The Supreme Court has itself recently reaffirmed the centrality of this principle, which it calls a "mainstay of our system of government," in the case of Gutierrez de Martinez v. Lamagno. ${ }^{155}$ The Court traces the principle's venerable pedigree, from the philosophy of Publius Syrus ${ }^{156}$ and Blaise

149. 3 U.S. (3 Dall.) 386 (1798).

150. Id. at 388 (opinion of Chase, J.).

151. Chase's broader theme in Calder-reading natural law requirements into the Constitution independent of textual or legal bases-has met with mixed levels of regard over the years. See, e.g., Seminole Tribe v. Florida, 116 S. Ct. 1114, 1177 (1996) (Souter, J., dissenting) (accusing majority of adhering to Chase's placement of natural law over constitutional text).

152. The Federalist No. 10, at 79 (James Madison) (Clinton Rossiter ed., 1961).

153. See id. at 83-84 (describing new Constitution as "proper structure of the Union" that provides "a republican remedy for the diseases [i.e., faction] most incident to republican government").

154. In re Sealed Motion, 880 F.2d 1367, 1369 (D.C. Cir. 1989) (quoting S. REP. No. 95-170, at 5 (1977)).

155. $115 \mathrm{~S}$. Ct. 2227, 2233 (1995). This case involved a finding by the Attorney General that a DEA agent, who was alleged to have acted negligently in an accident, had acted within the scope of his employment. See id. at 2229-30. The Court found that such determinations must be reviewable to avoid running afoul of the structural distaste for self-judging-in this case, agencies determining their own liability. See id. at 2233.

156. See id. ("No one should be judge in his own cause.") (citation omitted). 
Pascal, ${ }^{157}$ to the influential writings of Blackstone, ${ }^{158}$ to the Supreme Court cases of In re Murchison ${ }^{159}$ and Spencer v. Lapsley. ${ }^{160}$

Though there are relatively few constitutional cases concerning selfjudging, those that can be found are unanimous in their respect for the principle that no man shall be the judge in his own case. The cases indicate that not only is this a venerable principle of philosophy and history, it is an integral part of the structure of our constitutional government.

\section{The Rule of Law}

The other relevant principle deeply rooted in our constitutional heritage is that the Constitution establishes a system in which the rule of law is supreme. Expressed most famously in Marbury v. Madison, ${ }^{161}$ the principle that ours is "a government of laws, and not of men"162 was more thoroughly explicated in United States v. Lee: $:^{163}$

No man in this country is so high that he is above the law. No officer of the law may set that law at defiance with impunity. All the officers of the government, from the highest to the lowest, are creatures of the law and are bound to obey it.

It is the only supreme power in our system of government, and every man who by accepting office participates in its functions is only the more strongly bound to submit to that supremacy, and to observe the limitations which it imposes upon the exercise of the authority which it gives. ${ }^{164}$

157. See id. ("It is not permitted to the most equitable of men to be a judge in his oun cause") (citation omitted).

158. See id. ("“[I]t is unreasonable that any man should determine his own quarrel ".) (alteration in Gutierrez) (quoting I WILLIAM BLACKSTONE, COMMENTARIES *91); see also Bonham's Case. 77 Eng Rep 646, 652 (1610) ("IA liquis non debet esse Judex in proprio causa . . . . (No man should be a judge in his own cause]) (citation omitted).

159. See Gutierrez, 115 S. Ct. at 2233 ("'-[O]ur system of law has always endeavored to prevent even the probability of unfaimess. To this end no man can be a judge in his own case ..") (alteration in original) (quoting In re Murchison. 349 U.S. 133. 136 (1955)). Murcheson involved a defendant's nght to a fair tribunal, not self-judging per se. In Murchison, a judge presided over a contempt procecding regarding a separate forum in which he had personal involvement. See 3.49 U S at $136 \mathrm{He}$ was nol. however, judging himself. Nevertheless, this case show's that the Cour is quite comfonable using self. judging language as a basis for restraining the actions of govemment officials.

160. See Gutierrez, 115 S. Ct. at 2233 (quoting Spencer v. Lapsley. 61 U S (20 How) 26: 266 (1857) (discussing statutory standards for judge's recusal from case in which he may be biased)) This case is more analogous to a President pardoning his friends (which, we have seen, is less problematic) than to self-pardons. Nevertheless, it too exemplifies the power of the precedentual language agaınst self-judging

161. 5 U.S. (1 Cranch) 137 (1803).

162. Id. at 163 . The expression originally appeared in the Massachusetts Constitution of 1780. pt. 1. art. XXX, where it refers to the separation of powers. See Momson v. Olson. 487 U.S 65.4. 697 (1988) (Scalia, J., dissenting).

163. 106 U.S. 196 (1882).

164. Id. at 220. In Lee, land in what is now Arlington National Cemetery was seized by the federa! government, allegedly without just compensation. The United States argued that the fact that the officers who seized the estate were acting under orders from the President immunized the seizure from any judictal inquiry; the Court disagreed. See id. at 219-20. 
One can argue, of course, that "the authority" that the law "gives" to the President includes a pardon power that can be read as plenary. Even if this were so, however, the spirit of the declarations in Marbury and Lee would be violated by the actions of a President to remove himself from the purview of the federal criminal law. If he is truly deserving of a pardon, he can appeal to the rightful authorities-the prosecutor, the judge, the juries, and his successor as President-just like every other citizen must do. ${ }^{165}$ This, it seems, is the message of Marbury and Lee, a message of leveling and equality under the rule of law.

It is a message that has been received and amplified by subsequent Courts. As with self-judging, there are not very many cases regarding the status of constitutional actors, and those that do exist deal with matters that are more clear-cut than self-pardons. The most relevant language is found in a series of cases concerning the liability and immunity of public officials in suits brought against them. The cases cover Senators, ${ }^{166}$ Representatives, ${ }^{167}$ judges, ${ }^{168}$ and the President himself. ${ }^{169}$ In the latter case, a strong dissent reminds the Court of the "unanswerable argument that no man, not even the president of the United States, is absolutely and fully above the law.",170

While none of these cases match the rule of law against a broad constitutional provision like the pardon, and while the fact that the President is not always above the law does not necessarily mean that the President is never above the law, restricting officials within the bounds of the law is clearly a significant structural theme. When combined with the theme of non-selfjudging, it provides plenty of fodder for the Schick test.

Ultimately, the case law provides ample doctrinal basis for holding a selfpardon invalid. The Schick standard carves out an exception to the broad pardon power, forbidding those variations of it that "offend" the Constitution. The offensiveness of self-pardons is emphatically evident from cases like Gutierrez, Lee, Marbury, and many others, which show that forbidding selfjudging and maintaining the rule of law are central to our system of

165. See supra text accompanying note 114

166. See Burton v. United States, 202 U.S. 344, 368 (1906) (citing Lee, 106 U.S. at 220).

167. See Davis v. Passman, 442 U.S. 228, 246 (1979) (citing Lee, 106 U.S. at 220).

168. See Butz v. Economou, 438 U.S. 478, 506 (1978) (citing Lee, 106 U.S. at 220; Marbury, 5 U.S. (1 Cranch) 137); see also United States v. Hastings, 681 F.2d 706, 711 (11th Cir. 1982) (citing Lee, 106 U.S. at 220).

169. See Nixon v. Fitzgerald, 457 U.S. 731, 797 (1982) (Blackmun, J., dissenting) (citing Lee, 106 U.S. at 220; Marbury, 5 U.S. (1 Cranch) at 163). Nixon held that the President is above the law-that is, that he is immune from liability for acts he performs as President. Nevertheless, the language in the dissent clearly shows the importance and prominence of Lee. For a reading of temporary presidential (criminal) immunity as consistent with the invalidity of self-pardons, see Akhil Reed Amar \& Brian C. Kalt, The Presidential Privilege Against Prosecution, 2 NExus (forthcoming 1997).

170. Nixon, 457 U.S. at 798 (Blackmun, J., dissenting). Blackmun, joined by Brennan and Marshall, refers to this principle as "the foundation of our national jurisprudence." Id. (Blackmun, J., dissenting) (emphasis added). 
government. As a result, self-pardons are repugnant to our system, and they are not constitutionally valid.

\section{CONCLUSION}

A particularly interesting variation on Lee and Marbury is found in the words of President Gerald Ford: "Although I respected the tenet that no man should be above the law, public policy demanded that I put Nixon-and Watergate-behind us as quickly as possible." 171

At first glance, this may seem to muddle the themes discussed here. Ford understood that he was using his pardon power for the benefit of public policy, to heal the nation. He was wrong, though, in thinking that the pardon had placed Nixon above the law. Nixon was pardoned legally and legitimately by a President who had no improper personal stake in the matter. Consider, by contrast, how hollow Ford's words would have sounded if they had been spoken instead by Nixon. If Nixon had pardoned himself he would have been placing himself above the law, no matter how good his public policy intentions might have been. He would have been the judge in his own case. He would have clashed with the structure of the Constitution. His action would have been invalid.

It is important to examine the legality of self-pardons now, while the act is still a hypothetical one. An attempted self-pardon would likely undermine the public's confidence in the presidency and the Constitution. A potential meltdown of such magnitude would be no time to begin legalistic discussion; the political facts of the moment would distort our considered legal judgment. Looking at the question from a cooler vantage point, the intent of the Framers, the words and themes of the Constitution they created, and the wisdom of the judges that have interpreted it all point to the same conclusion: Presidents cannot pardon themselves.

171. GERALD R. FORD, A TIME TO HEAL 173 (1979). 


\section{.}

